\title{
Lyfjamál í brennidepli
}

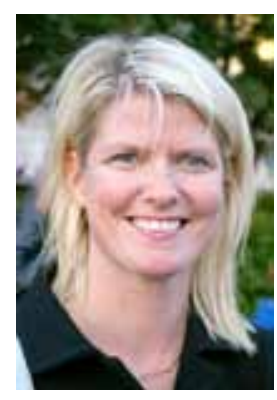

Gerður Gröndal

Gigtarlæknir á Landspítala gerdurgr@landspitali.is

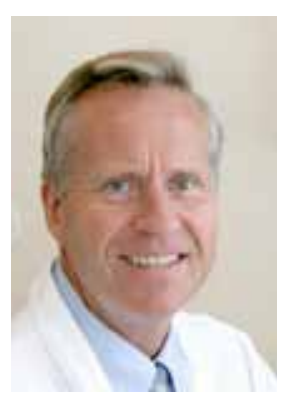

Einar S. Björnsson

Meltingarlæknir á Landspítala einarsb@landspitali.is
Lyfjakostnaður verður sífellt hærri á Vesturlöndum og líklega mun hann aukast sem hlutfall af kostnaði við heilbrigðismál á næstu árum. Lyfjanotkun hefur verið mikil á Íslandi og notkun nýrra lyfja verið með pví meira sem gerist. Petta á pó alls ekki við um öll lyf. Frá árinu 2001 hafa læknar á Íslandi sótt um til deildar lyfjamála á Landspítala og síðar Lyfjanefndar Landspítala fyrir notkun á svokölluðum S-lyfjum sem eru dýr og vandmeðfarin lyf. Leyfi eru gefin tímabundið og upplýsingar um árangur meðferðar fengnar áður en áframhaldandi leyfi er gefið. Petta verklag tíðkast ekki í nágrannalöndum okkar. Hérlendis hafa S-lyf pví verið notuð á mjög ábyrgan hátt. Pessi lyf eru gríðarlega dýr, kostnaður við pau var 5,4 milljarðar kr. árið 2012 og á fjárlögum 2013 er gert ráð fyrir 5,9 milljörðum kr.

Árið 2011 skipaði velferðarráðuneytið nefnd til pess að leita leiða til sparnaðar í S-lyfjum. Niðurstaðan var að aðhaldi hafi verið beitt til hins ýtrasta í mörg ár og ekki væri unnt að ná sparnaði í pessum lyfjakostnaði nema með pví að taka sjúklinga af lyfjum og takmarka aðgang sjúklinga að pessum lyfjum. Einu mögulegu sparnaðarleiðirnar sem nefndin benti á voru lækkun kostnaðar í innkaupum og takmörkun meðferðar. Í skýrslunni segir: „Ákvörðunartaka af pessu tagi krefst stefnumótunar af pví tagi sem nefndin hefur ekki á sínu færi að ljúka á stuttum tíma. Að pví verki pyrftu margir aðilar að koma, stjórnmálamenn, samtök sjúklinga, læknar og annað heilbrigðisstarfsfólk sem og siðfræðingar."

Prátt fyrir efnahagshrunið er mikilvægt að tryggja gæði heilbrigðispjónustunnar og sambærilega lyfjameðferð og í nágrannalöndunum. Í samkomulagi Sjúkratrygginga Íslands (Sí) og Landspítala frá 1. júní 2011 var gert ráð fyrir að við upptöku nýrra lyfja og gerð klínískra leiðbeininga yrði miðað við að lyfið væri komið í notkun í fjórum af fimm viðmiðunarlöndum, sem eru Norðurlöndin og Bretland. Að mörgu leyti eru petta eðlilegar kröfur enda engin sérstök ástæða til pess að Ísland sé að prófa ný og dýr lyf fyrst allra landa. Síðan varð sú stefnubreyting yfirvalda 2012 að eingöngu ætti að miða við leiðbeiningar National Institute for Health and Care Excellence (NICE) í Bretlandi varðandi meðferð með S-lyfjum.

Á vegum NICE eru gerðar vandaðar klínískar leiðbeiningar og kostnaðarábatagreining sem sjálfsagt er að nota sér við mat á nýjum lyfjum. Við ákveðna sjúkdóma, svo sem krabbamein, er pó ekki sambærilegur aðgangur að lyfjameðferð í Bretlandi og á Norðurlöndunum. Раð er samdóma álit lyfjanefndar að meðferð og gæði heilbrigðispjónustu eigi að vera sambærileg við pað sem gerist á Norðurlöndunum en ekki eigi að miða við Bretland, enda árangur af til dæmis krabbameinsmeðferð mun lakari par en hér og á hinum Norðurlöndunum.

Síðustu ár hefur upptaka nýrra lyfja, par með talið krabbameinslyfja, verið mjög takmörkuð hér á landi. Ákveðin krabbameinslyf hafa pví ekki verið aðgengileg hér, prátt fyrir að NICE hafi pegar fjallað um pau og sampykkt notkun peirra og pau séu líka notuð á Norðurlöndum. Breskir krabbameinssjúklingar hafa svo aðgang að nýjum lyfjum í gegnum aðrar opinberar leiðir, svo sem Cancer Drugs Fund (CDF) sem settur var á laggirnar árið 2011. Einnig hafa breskir sjúklingar aðgang að klínískum lyfjarannsóknum en slíkt er ekki í boði fyrir íslenska sjúklinga.
Mjög fá ný lyf hafa verið sampykkt til greiðslupátttöku af Sí frá 2010, prátt fyrir ítrekaðar óskir par um. Í tillögum SÍ frá 1. nóvember 2011 var sett fram áætlun um innleiðingu nýrra S-lyfja sem ekki hefur gengið eftir. Petta hefur leitt til pess að sjúklingar á Íslandi hafa ekki einu sinni aðgang að peirri meðferð sem mælt er með í klínískum leiðbeiningum frá NICE. Ekki er ljóst hvert hlutverk SÍ á að vera í pessu samhengi. Hin faglega sérpekking sem er nauðsynleg til að meta ábendingar pessara dýru og nýju lyfja er meðal sérfræðinga á Landspítala.

раð hefur nýlega komið í ljós að verð á sumum dýrum lyfjum á Íslandi er mun hærra en á Norðurlöndunum. Nefna má sem dæmi lyf við sortuæxli par sem útboð á Íslandi gaf 2\% afslátt en raunafsláttur í Noregi var 20\%. Ljóst er að bregðast parf við pessu, til dæmis með samvinnu um innkaup með einu af Norðurlöndunum, svo sem Noregi, en pví miður fyrir íslenska ríkið og skattgreiðendur torvelda samkeppnislög pess konar fyrirkomulag.

Við teljum mjög mikilvægt að við Íslendingar drögumst ekki aftur úr peim pjóðum sem við berum okkur saman við hvað varðar lyfjameðferð. Раð er pó engu að síður mikilvægt að læknar sýni samfélagslega ábyrgð og fylgi klínískum leiðbeiningum við ávísun á dýr og vandmeðfarin lyf.

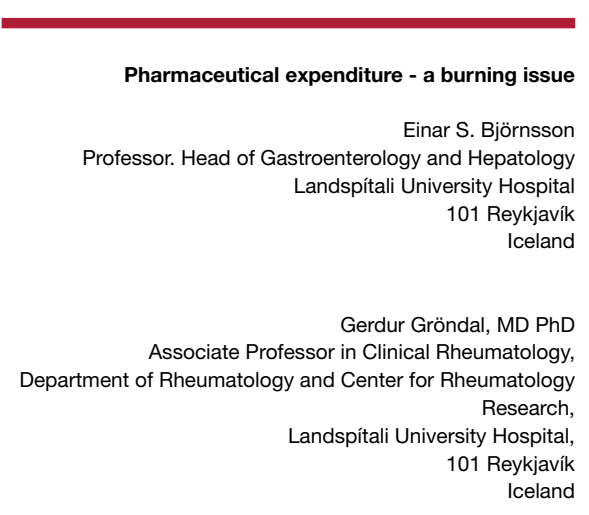

